\section{Effects of Papain-Based Gel Used For Caries Removal on Macrophages and Dental Pulp Cells}

Laura Alves Bastos ${ }^{1}$ [Drancine Lorencetti Silva ${ }^{1}$ (D) João Pedro de Queiroz Thomé $^{2}$ - Maya Fernanda Manfrin Arnez ${ }^{1}$ [Décia Helena Faccioli ${ }^{3}$ (i) Francisco Wanderley Garcia Paula-Silva ${ }^{1,3}$ (D)

\begin{abstract}
Papain-based gel is used for chemical-mechanical caries removal and present antimicrobial and anti-inflammatory activities. However, its effects on dental pulp cells and on macrophages remains largely unknown. Therefore, the aim of this study was to investigate whether the papain-based gel Papacárie Duo ${ }^{\circledR}$ acts as an immunomodulator in lipopolysaccharide (LPS)-activated macrophages and its effects on dental pulp cells. J774.1 macrophage and OD-21 dental pulp cells were stimulated with 0.5\% and 5\% of Papacárie Duo ${ }^{\circledR}$, following pre-treatment or not with LPS. After $24 \mathrm{~h}$, a lactate dehydrogenase assay was used to measure cytotoxicity, a tetrazolium-based colorimetric assay (MTT) was used to measure cell viability, and qRT-PCR was used to analyze relative gene expression of Ptgs2, Il10, Tnf, Mmp9, Runx2, Ibsp and Spp1. Papacárie Duo ${ }^{\circledR}$ was cytotoxic and reduced cell viability at $5 \%$ but not at $0.5 \%$ in both cultures. In macrophages, Papacárie Duo ${ }^{\circledR}$ increased the expression II10 and LPS-induced Ptgs2, but it did not affect Tnf or Mmp9. In OD-21 cells, Papacárie Duo ${ }^{\circledR}$ inhibited Runx2 and Ibsp expression, but stimulated Spp1 expression. Papain-based gel presented a concentration dependent cytotoxicity, without affecting cell viability, for dental pulp cells and macrophages. Interestingly, the gel presented an inhibitory effect on pulp cell differentiation but modulated the activation of macrophages stimulated with LPS. We speculate that in dental pulp tissue, Papacárie Duo ${ }^{\circledR}$ would impair reparative dentinogenesis but could activate macrophages to perform their role in defense and inflammation.
\end{abstract}

${ }^{1}$ Department of Pediatric Clinics, USP - Universidade de São Paulo, Ribeirão Preto, SP, Brazil ${ }^{2}$ FACISB - Faculdade de Ciências da Saúde de Barretos Dr. Paulo Prata, Barretos, SP, Brazil ${ }^{3}$ Departamento de Análises Clínicas, Toxicológicas e Bromatológicas, Laboratório de Inflamação e Imunologia das Parasitoses, Faculdade USP - Faculdade de Ciências Farmacêuticas de Ribeirão Preto, Ribeirão Preto, SP, Brazil

Correspondence: Francisco Wanderley Garcia de Paula-Silva, Avenida do Café, s/nº, 14040-904 Ribeirão Preto, SP, Brasil. Tel: +55-3315-4113. e-mail: franciscogarcia@forp.usp.br

\section{Introduction}

The success of chemo-mechanical caries removal relies on the selectivity of removing the carious tissue, which reduces the bacterial load in the interior of the cavity without removing the tissue that is capable of remineralization $(1,2)$. This method can minimize the unpleasant perception that occur during caries removal by the conventional method (3). Some methods are becoming more popular and being improved to minimize the number of interventions and to maximize the preservation of dental tissues during removal of carious tissues (4).

The dentin is permeated by tubules that converge as they approach more internal areas. Therefore, the tubule diameter varies in relation to the distance towards the surface of the coronary chamber (5). The fact that dentin and the pulp tissue are intimately connected requires dental materials to be biocompatible and to ideally present antiinflammatory properties. Some materials are biocompatible with the dentin-pulp complex when applied to superficial and moderate cavities, but when applied to deeper cavities may be toxic to the pulp tissue or may adversely affect the repair process (6). Papacárie Duo ${ }^{\circledR}$ is a material developed for chemo-mechanical caries removal and consists mainly of papain (7), which has antimicrobial properties $(3,8,9)$. This papain-based gel is basically composed of a proteolytic enzyme that interacts with the partially degraded collagen present in the necrotic carious tissue (7). Some studies have addressed the effects of chemo-mechanical caries removal agents, in terms of clinical efficacy, acceptability, levels of pain, and success in the long term $(3,10-14)$. The effects of Papacárie Duo ${ }^{\circledR}$ on macrophage behaviour is not known, and its effects in cytotoxicity, viability and differentiation of undifferentiated dental pulp cells is scarce.

Therefore, the aim of this study was to determine whether Papacárie Duo ${ }^{\circledR}$ acts as an immunomodulator of macrophages activated or not by lipopolysaccharide (LPS) and evaluate its effects on cytotoxicity, viability and differentiation of dental pulp cells. Our null hypothesis is that Papacárie Duo ${ }^{\circledR}$ is neither cytotoxic nor impair cell function.

\section{Material and Methods Macrophage Culture (J774.1)}

The J774.1 murine macrophage cell line was obtained from the American Type Culture Collection (ATCC, Rockville, MD, USA). Cells were cultured in DMEM medium supplemented with $10 \%$ fetal bovine serum and $1 \%$ 
Penicilin/Streptomicin (Gibco, Grand Island, NY, USA) (DMEM). After the formation of a monolayer, cells were harvested with plastic cell scrapers and centrifuged at $1,500 \mathrm{rpm}$ for $10 \mathrm{~min}$ at $10{ }^{\circ} \mathrm{C}$. Next, supernatants were discarded and $10 \mathrm{~mL}$ of DMEM was added to each tube of cells. Cell viability and total cell numbers were determined by counting live and dead cells in a Neubauer chamber (BOECO Germany, Hamburg, Germany) after staining with Trypan blue (Gibco). Cells were plated in 96-well culture plates (Cell Wells - Corning Glass Workers, Corning, NY, USA) at a density of $1 \times 10^{5}$ cells / well and incubated overnight in DMEM in an incubator with a moist atmosphere of 5\% $\mathrm{CO}_{2}$ at $37^{\circ} \mathrm{C}$.

\section{Pulp cell culture (OD-21)}

Undifferentiated mouse pulp cells (OD-21) (15) were maintained in Dulbecco's Modified Eagle Medium (DMEM) supplemented with 10\% fetal bovine serum (FBS) (Gibco) and $1 \%$ Penicillin/Streptomycin (Gibco) in an incubator at $37{ }^{\circ} \mathrm{C}$ and $5 \% \mathrm{CO}_{2}$. For the experiments, $1 \times 10^{5}$ cells/well were plated in 96-well cell culture plates (Corning Glass Workers) using DMEM without FBS.

\section{Preparation of Papacárie Duo ${ }^{\circledR}$ Solutions}

Papacárie Duo ${ }^{\circledR}$ gel $(1 \mathrm{ml}$ syringe) (Formulation \& Action, São Paulo, SP, Brazil) was prepared by serial dilution in DMEM without FBS to obtain concentrations ranging from $0.005 \%$ up to $50 \%$. In pilot studies, we found that concentrations lower than $0.5 \%$ had no effect on cell viability and higher than $5 \%$ cell death was high (> 80\% of the cells). Thus, we chose to investigate $5 \%$ and $0.5 \%$ Papacárie Duo ${ }^{\circledR}$ solutions.

J774.1 cells were pre-stimulated with LPS $(0.5 \mathrm{mg} /$ $\mathrm{mL}$; Escherichia coli LPS, Sigma-Aldrich, St. Louis, MO, USA) for $2 \mathrm{~h}$. After the pre-stimulation, the culture medium was removed and the cells were washed with $1 \mathrm{x}$ Phosphate Saline Buffer (PBS). Then, $200 \mu \mathrm{L}$ of $0.5 \%$ and $5 \%$ Papacárie Duo ${ }^{\circledR}$ solutions, containing LPS or not, were added to each well. Cells exposed to LPS only were used as a positive control and cells maintained in DMEM without serum were used as a negative control. OD-21 had culture medium removed and the wells washed with PBS. Then, $200 \mu \mathrm{L}$ of $0.5 \%$ and $5 \%$ Papacárie Duo ${ }^{\circledR}$ solution were added to each well. Following incubation, the stimuli were removed and the plates were either assayed or stored at $-80{ }^{\circ} \mathrm{C}$. The experiments were performed in triplicates and replicated twice. Experimentation and data collection was performed in an open label format. Data were then codified and analysis were performed blindly.

Cytotoxicity - Lactate Dehydrogenase (LDH) Assay
The cytotoxicity of 0.5 and 5\% Papacárie Duo ${ }^{\circledR}$ solutions was evaluated on J774.1 macrophage cells and OD-21 cells by measuring the level of LDH released in the supernatant after cell lysis using the CytoTox96 ${ }^{\circledR}$ non-radioactive cytotoxicity assay (Promega Corporation, Madison, WI, USA). The absorbance was measured at $490 \mathrm{~nm}$ with a spectrophotometer (mQuanti, Bio-Tek Instruments, Inc., Winooski, VT, USA). As positive control, $10 \times$ Lysis Solution was added to the cells, $45 \mathrm{~min}$ prior to adding CytoTox $96^{\circledR}$ Reagent. LDH levels were expressed as percentages, according to the formula: cytotoxicity (\%) $=100 \times$ Experimental LDH Release absorbance / Maximum LDH Release absorbance (positive control).

\section{Cell Viability - MTT Colorimetric Assay}

Cell viability was evaluated using an MTT assay according to the manufacturer's instructions. J774. 1 cells ( 1 $\times 10^{5} /$ well), with or without LPS, and OD-21 cells $\left(1 \times 10^{5} /\right.$ well) were plated in 96-well plates and stimulated for $24 \mathrm{~h}$ with Papacárie Duo ${ }^{\circledR}$ solutions at different concentrations. Dimethyl sulfoxide (DMSO) was used as positive control.

The stimuli were removed and $10 \mu \mathrm{L}$ of MTT (3-(4,5-dymethylthiazol-2-yl)-2,5-diphenyltetrazoluim bromide, Sigma-Aldrich C0., Catalog number M2128) supplemented with $150 \mu \mathrm{L}$ Roswell Park Memorial Institute (RPMI) medium 1640 (Gibco) was added to the plates. After $3 \mathrm{~h}$ incubation at $37^{\circ} \mathrm{C}, 40 \mu \mathrm{L}$ of sodium dodecyl sulphate (SDS) buffer was added and cell viability was determined using a SpectraMax ${ }^{\circledR}$ Paradigm $^{\circledR}{ }^{\circledR}$ spectrophotometer (Molecular Devices, LLC, Sunnyvale CA, USA). Cell viability was expressed as percentages, according to the formula: cell viability $(\%)=100 \times$ Experimental absorbance $/$ Negative control absorbance (medium alone).

\section{RNA Extraction, Reverse Transcription, and Polymerase Chain Reaction In Real Time (Qrt-PCR)}

To evaluate J774.1 cell activation and OD-21 cell differentiation, the mRNA levels of Ptgs2, II10, Tnf, and Mmp9, and Ibsp, Runx2, and Spp1, respectively, were measured by quantitative reverse transcriptase-polymerase chain reactions ( $\mathrm{RRT}-\mathrm{PCR}$ ) $24 \mathrm{~h}$ after cell stimulation. To this end, total RNA was extracted using the RNeasy ${ }^{\circledR}$ Mini kit (Qiagen Inc., Valencia, USA) and quantified using NanoDrop 2000 spectrophotometer (Thermo Fisher Scientific Inc., Wilmington, USA). A total of $800 \mathrm{ng}$ of total RNA were used for cDNA synthesis with the High Capacity cDNA Reverse Transcription kit (Applied Biosystems, Foster City, USA) in a thermal cycler (Veriti ${ }^{\circledR}$ Thermal Cycler, Applied Biosystems, USA). qRT-PCR reactions were performed in duplicate using the $\operatorname{TaqMan}^{\circledR}$ system in a StepOne Plus $^{\circledR}$ real-time PCR system (StepOne Plus ${ }^{\circledR}$ Real-Time PCR System, Applied Biosystems) and the following cycle 
program: $95{ }^{\circ} \mathrm{C}$ for $20 \mathrm{~s}, 40$ cycles at $95{ }^{\circ} \mathrm{C}$ for $1 \mathrm{~s}$, and $60{ }^{\circ} \mathrm{C}$ for $20 \mathrm{~s}$. All protocols were performed according to the manufacturers' instructions. Primer-probe pairs were obtained commercially, thus their sequences are not available (Applied Biosystems). Glyceraldehyde-3-phosphate dehydrogenase (Gapdh) and beta-actin (Actb) were used as reference genes for normalization purposes. The results were analyzed based on cycle threshold (Ct) values. Relative expression was calculated by the $\Delta \Delta \mathrm{Ct}$ method.

\section{Statistical Analysis}

For each experiment, data were compared using analysis

\section{A}

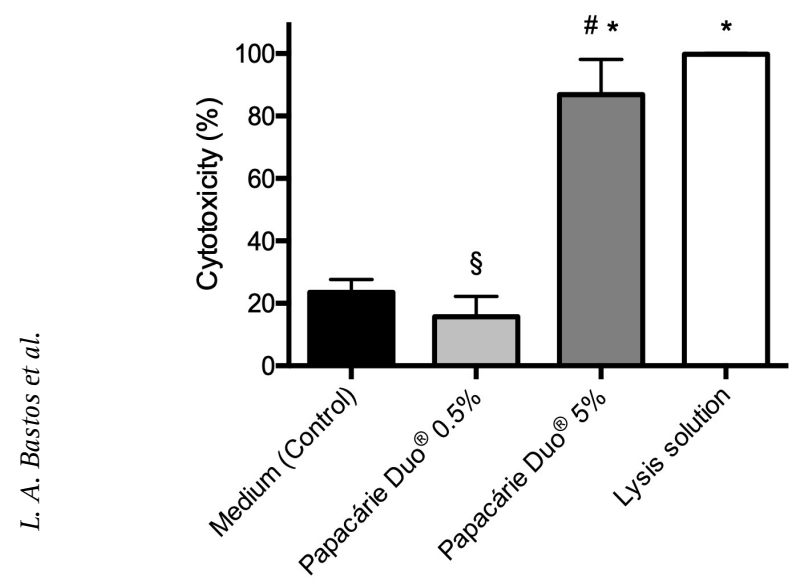

B

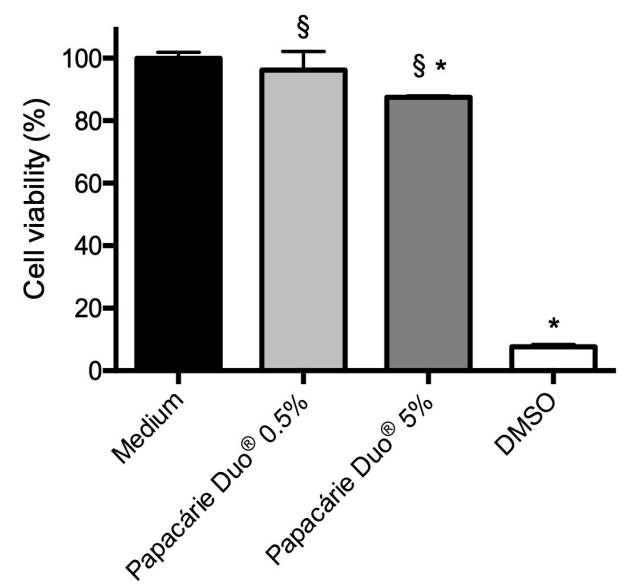

Figure 1. Papacárie Duo ${ }^{\circledR}$ cytotoxicity in macrophages (J774.1) by LDH assay (A) and cell viability by MTT assay after $24 \mathrm{~h}$ (B). Lysis solution or DMSO were used as positive control. Untreated cells (culture medium) were used as a negative control ${ }^{*} \mathrm{p}<0.05$ compared to culture medium alone; $\$ \mathrm{p}<0.05$ compared to lysis buffer or DMSO; \# p $<0.05$ compared to Papacárie Duo ${ }^{\circledR} 0.5 \%$. of variance (ANOVA) followed by the Tukey's test ( $\alpha=0.05$ ) using Graph Pad Prism Software version 6.0.

\section{Results}

\section{Cytotoxicity and Cell Viability}

The 5\% Papacárie Duo ${ }^{\circledR}$ solution was cytotoxic to macrophages $(p<0.05)$. However, at $0.5 \%$ concentration, no cytotoxicity was observed $(p>0.05)$ when compared to positive and negative controls (Fig. 1A). The same pattern was observed for cell viability (Fig. 1B). In the presence of LPS, no cytotoxicity was observed ( $p>0.05$ ) (Fig. 2A), but cellular viability was reduced, regardless of the presence

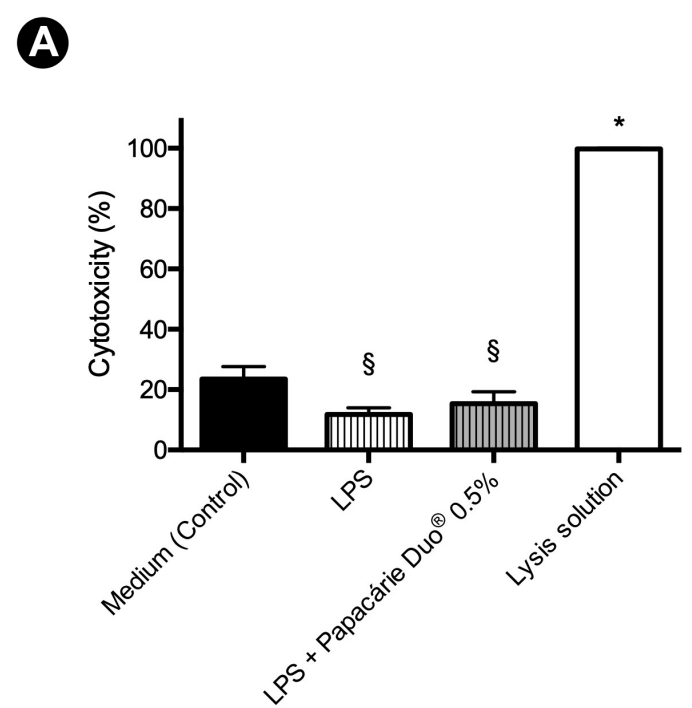

B

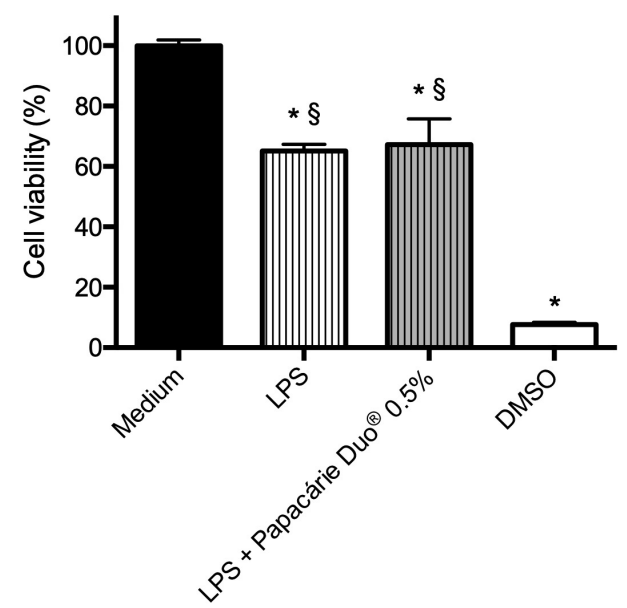

Figure 2. Papacárie Duo ${ }^{\circledR}$ cytotoxicity in undifferentiated dental pulp cells (OD-21) by LDH assay (A) and cell viability by MTT assay after $24 \mathrm{~h}$ (B). Lysis solution or DMSO were used as positive control. Untreated cells (culture medium) were used as a negative control. ${ }^{*} \mathrm{p}<0.05$ compared to culture medium alone; $\$ \mathrm{p}<0.05$ compared to lysis buffer or DMSO; \# p $<0.05$ compared to 0.5\% Papacárie. 
of Papacárie Duo ${ }^{\circledR}(\mathrm{p}<0.05)$ (Fig. 2B).

In dental pulp cells, Papacárie Duo ${ }^{\circledR}$ was cytotoxic when applied at $5 \%(\mathrm{p}<0.05)$. However, it was not cytotoxic when applied at $0.5 \%$ ( $p>0.05)$, compared to positive and negative controls (Fig. 3A). Papacárie Duo ${ }^{\circledR}$ reduced cell viability in a dose-dependent fashion, compared to the culture medium alone ( $p>0.05$ ) (Fig. 3B).

\section{Cell Differentiation}

In undifferentiated dental pulp cells, Papacárie Duo ${ }^{\circledR}$ inhibited the expression of Runx2 $(p<0.05)$ and Ibsp $(p<0.05)$, while stimulated Spp1 expression ( $<<0.05)$ (Fig. 4).

Papacárie Duo ${ }^{\circledR}$ activated macrophages with or without LPS. LPS stimulated Tnf expression compared to negative

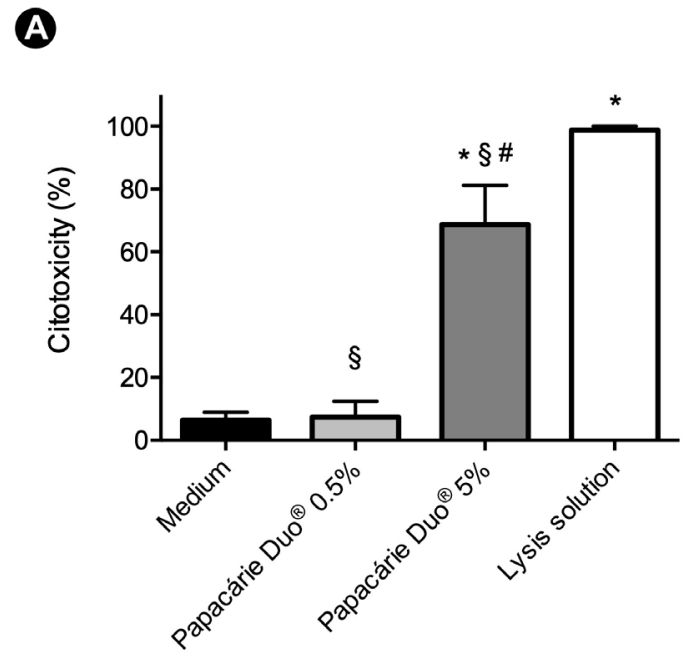

B

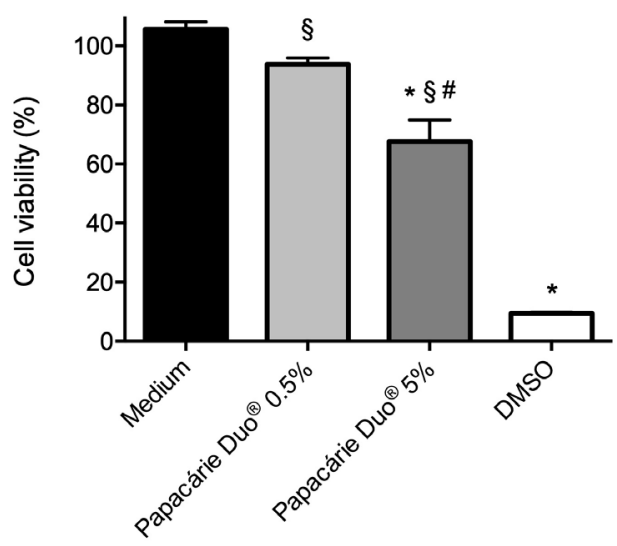

Figure 3. Papacárie Duo ${ }^{\circledR}$ cytotoxicity in undifferentiated dental pulp cells (OD-21) by LDH assay (A) and cell viability by MTT assay after $24 \mathrm{~h}$ (B). Lysis solution or DMSO were used as positive control. Untreated cells (culture medium) were used as a negative control. ${ }^{*} \mathrm{p}<0.05$ compared to culture medium alone; $\S \mathrm{p}<0.05$ compared to lysis buffer or DMS0; \# p<0.05 compared to 0.5\% Papacárie. control $(p<0.05)$, while the $0.5 \%$ Papacárie Duo ${ }^{\circledR}$ at solution did not change the LPS-induced Tnf expression ( $p>0.05$ ). Mmp9 expression was not altered by LPS or by Papacárie ${ }^{D u 0}{ }^{\circledR}$, or by the combination of both ( $\left.p>0.05\right)$. LPS induced expression of Ptgs2 $(p<0.05)$ and $0.5 \%$ PapacárieDuo ${ }^{\circledR}$ increased LPS-induced Ptgs2 expression $(p<0.05)$. On the

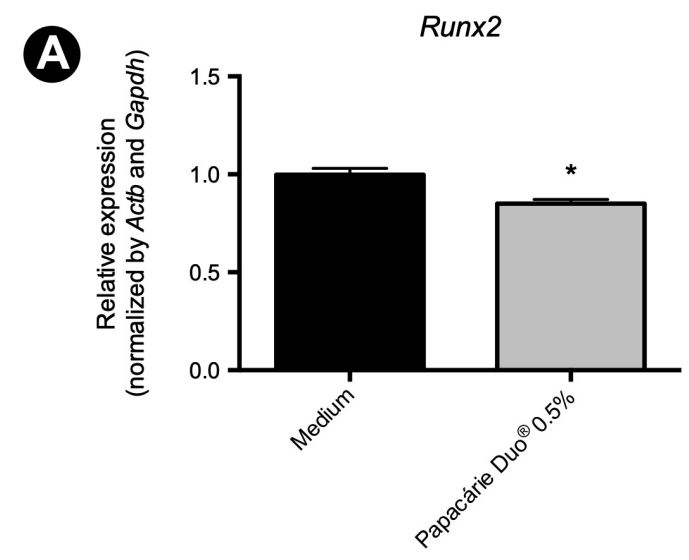

B

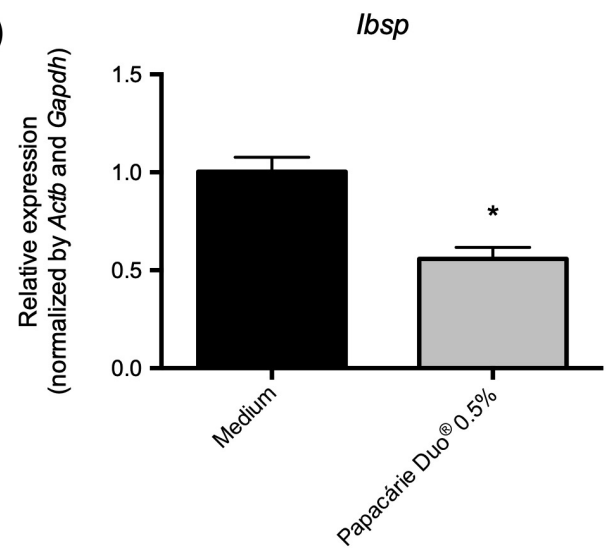

(C)

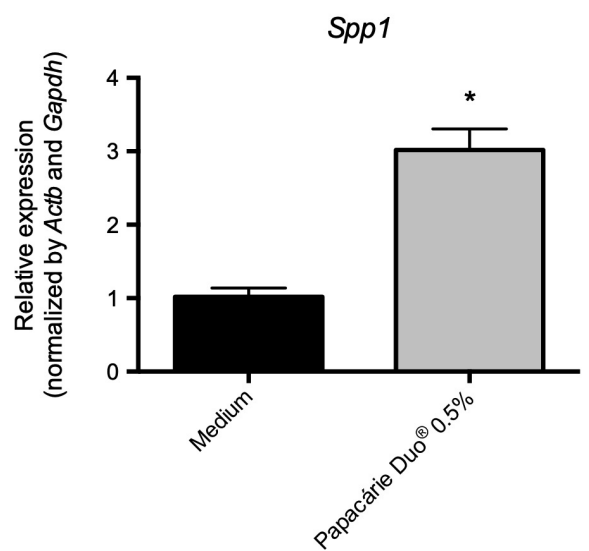

Figure 4. Effect of 0.5\% Papacárie Duo ${ }^{\circledR}$ on the expression of Runx2 (A), Ibsp (B) and Spp 1 (C) by undifferentiated dental pulp cells (OD-21) after $24 \mathrm{~h}$. Expression was analysed by qRT-PCR. ${ }^{*} \mathrm{p}<0.05$ compared to culture medium alone. 
other hand, 0.5\% Papacárie Duo ${ }^{\circledR}$ alone inhibited Ptgs2 expression $(p<0.05)$. Papacárie $\mathrm{Duo}^{\circledR}$ at $0.5 \%$, in the presence or not of LPS, stimulated II 10 expression $(p<0.05)$. However LPS alone did not modulate 1110 expression ( $p>0.05)$ (Fig. 5).

\section{Discussion}

The null hypothesis of this study was rejected because we found a concentration dependent effect of cytotoxicity, cell viability and cell function, i.e., activation of macrophages and differentiation of dental pulp cells. Papacárie Duo ${ }^{\circledR}$ at $0.5 \%$ solution was not cytotoxic to macrophages or dental pulp cells, but when used at $5 \%$ concentration reduced cell viability and was highly cytotoxic for both cultures. A previous study demonstrated that Papacárie Duo ${ }^{\circledR}$ cytotoxicity may also vary depending on the cell type on which it is applied. Major effects were found in periodontal ligament fibroblasts, epithelial cells and tumor cells of the oral mucosa. Minor cytotoxic effect was found in cells from human pulp and human gingival fibroblasts (16). These divergent effects might be due to cell type specific effects. OD-21 cells are from a mesenchymal lineage whereas J774.1 are from an hematopoietic lineage. The cytotoxicity of Papacárie Duo ${ }^{\circledR}$ was also tested on fibroblasts isolated from the central region of the pulp tissue and no cytotoxicity was observed (2).

It is noteworthy that the cytotoxicity of a material may also depend on the thickness of the remaining dentin and on dentin permeability $(6,17)$. Thus, considering that Papacárie Duo ${ }^{\circledR}$ is possibly cytotoxic to dental pulp cells (as indicated by the results at $5 \%$ concentration), the thickness of the remaining dentin after cavity preparation is a highly relevant factor. The thickness and morphological characteristics of the dentin may favor transdentinal diffusion of chemical components from the materials. Indeed, severe pulp reactions occur when the remaining dentin is low (18). Therefore, considering clinical parameters, deeper cavities require greater care and attention in choosing the dental

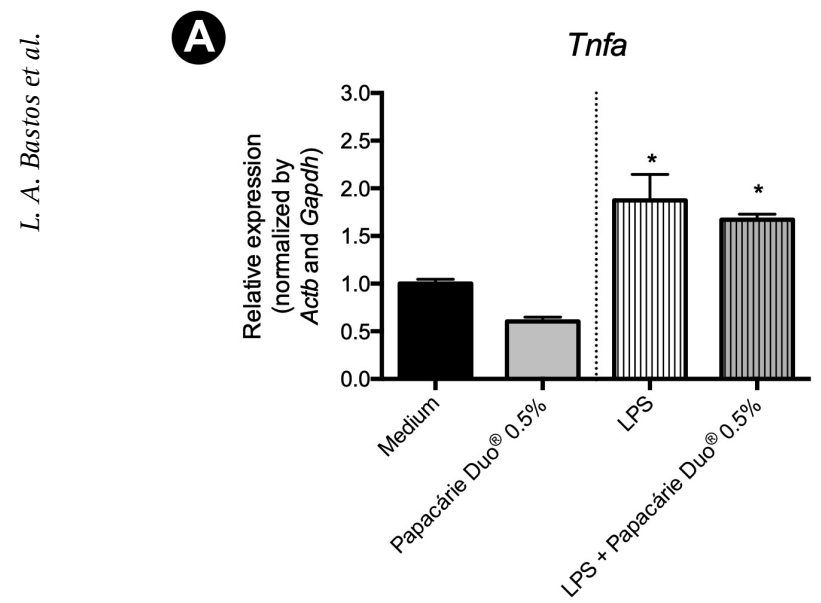

B

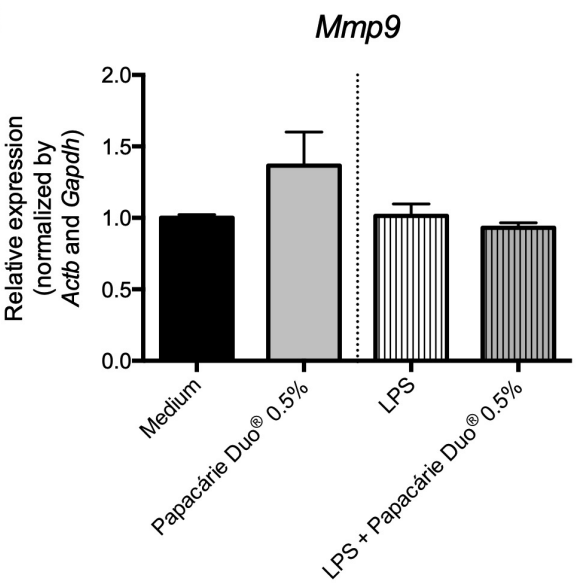

(D)

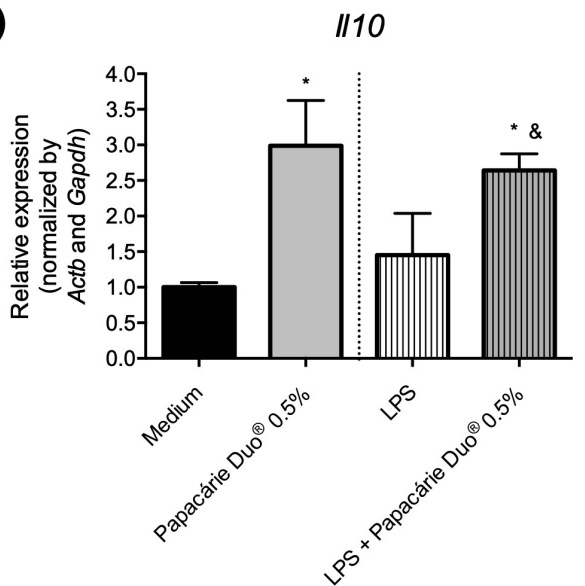

Figure 5. Effect of 0.5\% Papacárie Duo ${ }^{\circledR}$, alone or in combination with LPS, on the expression of Tnf (A), Mmp9 (B) Ptgs2 (C) and Il10 (D) by macrophages (J774.1) after $24 \mathrm{~h}$. Expression was analysed by qRT-PCR. * $\mathrm{p}<0.05$ compared to culture medium alone; and $\mathrm{Ct}$ p<0.05 compared to LPS. 
materials to be used, as improper handling or choice can result in significant damage to dental tissue and pulp. Also, the dilution effect of the dentinary fluid found in dentin tubules should be considered. This fluid can dilute the material, depending on its solubility, and therefore modify the intensity of the inflammatory response in the subjacent dental pulp tissue. The in vivo effect of Papacárie Duo ${ }^{\circledR}$ on dental pulp, when applied to dentin, is not know and deserves further investigation.

In our study, it was found increased expression of Ptgs2 and II10 mRNA in the presence of Papacárie Duo ${ }^{\circledR}$. Increased levels of the pro-inflammatory lipid mediator prostaglandin E2 (PGE2) was induced by Papacárie Duo ${ }^{\circledR}$ in gingival fibroblasts that were synergistically increased in presence of IL-1 $\beta$ (16). The Ptgs 2 gene encodes the COX-2 enzyme, which is responsible for the synthesis of prostaglandins involved in inflammatory response (19). IL-10 is an antiinflammatory cytokine and a modulator of macrophage activation during infection (20). Until now, nothing was known about the PapacárieDuo ${ }^{\circledR}$ immunomodulatory capacity in the presence or absence of LPS. Increased expression of Ptgs2 by PapacárieDuo ${ }^{\circledR}$ in the presence of LPS or induction of II10 expression in the presence or absence of LPS demonstrated that this material modulate macrophage activation and indicate that it could modulate the inflammatory response.

In contrast, undifferentiated dental pulp cells had the expression of Runx2 and Ibsp inhibited by Papacárie $\mathrm{Duo}^{\circledR}$. Runx2 regulates several signaling pathways related with odontoblast differentiation (21). Runx2 is expressed in odontoblast-like cells and in dental pulp stem cells located in the region of deposition of reparative dentin. This transcription factor promotes differentiation of pulp stem cells, enabling them to form repairing dentin $(22,23)$. Ibsp codes for a phosphorylated glycoprotein and is mainly expressed in mineralized connective tissues. It has several roles during development, regulating the volume and mineralization of bone and dentin tissues. Induction of this gene coincides with the initial formation of the mineralized matrix and maximum induction is achieved during bone formation $(24,25)$. Considering the roles of Runx2 and Ibsp in cell differentiation, it is expected that their inhibition results in suppression of differentiation of OD-21 cells. However, the expression of Spp1, a gene that codes for osteopontin (OPN) was induced. OPN is a highly phosphorylated glycoprotein that composes the bone extracellular mineralized matrix. It is important for inflammatory and mineralization events because it is capable of regulating several physiological and pathological processes, including wound healing, bone remodeling, tumorigenesis, inflammation and immunological responses (26). The protein is then deposited in the dentin-pre-dentin interface, prior to the differentiation of odontoblast-like cells. Therefore, OPN may have a role in the differentiation of these cells (27). Once deposited in the pulp-dentin border, OPN induces the formation of tertiary dentin and of type I collagen, which is essential for the development of a new mineralized matrix (28). Future studies are needed to clarify the role of Spp1, a gene related not only with mineralization but also with inflammatory events $(29,30)$ and to investigate the effect of Papacárie Duo ${ }^{\circledR}$ in other types of inflammatory cells, as well as in vivo.

In macrophages and undifferentiated dental pulp cells, Papacárie Duo ${ }^{\circledR}$ was cytotoxic and reduced cell viability at $5 \%$ but not at $0.5 \%$. In macrophages, Papacárie Duo ${ }^{\circledR}$ at $0.5 \%$ induced the expression $I 10$ and LPS-induced Ptgs2, but it did not affect Tnf or Mmp9 gene expression. In undifferentiated dental pulp cells, Papacárie Duo ${ }^{\circledR}$ at $0.5 \%$ inhibited Runx2 and Ibsp, while stimulated Spp1 expression. We speculate that in dental pulp tissue, Papacárie $D{ }^{\circledR}{ }^{\circledR}$ would impair reparative dentinogenesis but could activate macrophages to perform their role in defense and inflammation. Further studies should be conducted in vivo to confirm that.

\section{Resumo}

0 gel à base de papaína é utilizando para remoção químico-mecânica do tecido cariado e apresenta propriedades antimicrobianas e antiinflamatórias Entretanto, seu efeito sobre as células da polpa dentárias e macrófagos é desconhecido. Portanto, o objetivo deste estudo foi investigar o efeito de um gel de papaína (Papacárie Duo ${ }^{\circledR}$ ) em células indiferenciadas da polpa dentária e a capacidade de induzir a ativação e sintese de mediadores inflamatórios por macrófagos estimulados com lipopolissacarideo bacteriano (LPS). 0 gel de papaína foi diluído nas concentrações de 0,5 e 5\%. Células indiferenciadas da polpa dentária OD-21 e macrófagos J774.1 foram mantidos em cultura com os diferentes estímulos por um período de estimulação de $24 \mathrm{~h}$ para realização do teste de citotoxicidade (Ensaio LDH) e para avaliação da viabilidade celular (Ensaio Colorimétrico MTT). A seguir foi realizada avaliação da expressão gênica relativa dos genes Ibsp, Runx2 e Spp1 em células OD-21; e dos genes II10, Mmp9, Ptgs2 e Tnf em células J774.1, pelo método de transcrição reversa e reação em cadeia de polimerase em tempo real (qRT-PCR), após estimulação pelo período de $24 \mathrm{~h}$. 0 extrato do gel diluído a $5 \%$ foi citotóxico às células da polpa dental, reduziu a viabilidade celular, inibiu a expressão de Runx2 e Ibsp e estimulou a expressão de Spp1. Em macrófagos, o extrato do gel foi citotóxico e reduziu a viabilidade celular na concentração de 5\%. 0 LPS inibiu a viabilidade celular na presença ou não do extrato do gel, sem apresentar citotoxicidade. 0 extrato do gel induziu a expressão de Ptgs2 e II10, sem alterar Tnf e Mmp9. 0 extrato do gel de papaína foi citotóxico, dependente da concentração, tanto em células da polpa dentária como em macrófagos, sem alterar a viabilidade celular. Interessantemente, apresentou efeito inibitório na diferenciação de células da polpa dentária e modulou a ativação de macrófagos estimulados com LPS. No tecido pulpar, o Papacárie Duo ${ }^{\circledR}$ poderia impedir a dentinogênese de reparação, porém ativar macrófagos para desempenhar seu papel na inflamação e defesa.

\section{Acknowledgements}

The authors deny any conflicts of interest related to this study. We would like to thank Dr. Karina Fittipaldi Bombonato Prado from the School of Dentistry of Ribeirão Preto (FORP/USP) for providing OD-21 cells. This 
study was supported by Grants from São Paulo Research Foundation (FAPESP 2010/17611-4 to FWGPS and 2014/14015-2 to JPQT) and by the Coordenação de Aperfeiçoamento de Pessoal de Nivel Superior - Brasil (CAPES) - Finance Code 001 (Fellowships to LBA and FLS).

\section{References}

1. Fusayama T. Two layers of carious dentin; diagnosis and treatment. Oper Dent 1979;4:63-70.

2. Martins MD, Fernandes KP, Motta $\amalg$, Santos EM, Pavesi VC, Bussadori SK. Biocompatibility analysis of chemomechanical caries removal material Papacárie on cultured fibroblasts and subcutaneous tissue. J Dent Child (Chic) 2009;76:123-129.

3. Chowdhry S, Saha S, Samadi F, Jaiswal JN, Garg A, Chowdhry P. Recent vs Conventional Methods of Caries Removal: A Comparative in vivo Study in Pediatric Patients. Int J Clin Pediatr Dent 2015;8:6-11.

4. Hamama H, Yiu C, Burrow MF, King NM. Systematic Review and MetaAnalysis of Randomized Clinical Trials on Chemomechanical Caries Removal. Oper Dent. 2015;40:e167-178.

5. Pashley DH, Carvalho RM. Dentine permeability and dentine adhesion. J Dent 1997;25:355-372.

6. Costa $\mathrm{CA}$, Ribeiro AP, Giro EM, Randall RC, Hebling J. Pulp response after application of two resin modified glass ionomer cements (RMGICs) in deep cavities of prepared human teeth. Dent Mater 2011;27:e158-170.

7. Bussadori SK, Castro LC, Galvão AC. Papain gel: a new chemomechanical caries removal agent. J Clin Pediatr Dent 2005;30:115-119.

8. Hamama HH, Yiu CK, Burrow MF. Viability of intratubular bacteria after chemomechanical caries removal. J Endo. 2014;40:1972-1976.

9. Motta $\amalg$, Bussadori SK, Campanelli AP, Silva AL, Alfaya TA, Godoy

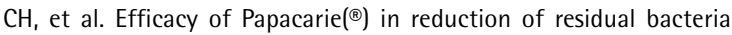
in deciduous teeth: a randomized, controlled clinical trial. Clinics 2014;69:319-322.

10. Goyal PA, Kumari R, Kannan VP, Madhu S. Efficacy and tolerance of papain gel with conventional drilling method: a clinico-microbiological study. J Clin Pediatr Dent 2015;39:109-112.

11. Neves AA, Lourenço RA, Alves HD, Lopes RT, Primo LG. Cariesremoval effectiveness of a papain-based chemo-mechanical agent: $A$ quantitative micro-CT study. Scanning 2015;37:258-264.

12. Motta $\amalg$, Bussadori SK, Campanelli AP, Silva AL, Alfaya TA, Godoy

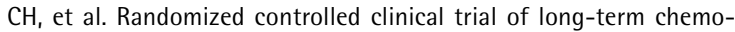
mechanical caries removal using Papacarie ${ }^{T M}$ gel. J Appl Oral Sci 2014;22:307-313.

13. Moimaz SAS, Okamura AQC, Lima DC, Saliba TA, Saliba NA. Clinical and microbiological analysis of mechanical and chemomechanical methods of caries removal in deciduous teeth. Oral Health Prev Dent 2019;17:283-288.

14. Bussadori SK, Guedes CC, Bachiega JC, Santis TO, Motta U. Clinical and radiographic study of chemical-mechanical removal of caries using Papacárie: 24-month follow up. J Clin Pediatr Dent 2011;35:251-254.

15. Hanks CT, Sun ZL, Fang DN, Edwards CA, Wataha JC, Ritchie HH, et al. Cloned 3T6 Cell Line from CD-1 Mouse Fetal Molar Dental Papillae.
Connective Tissue Res 1998;37:233-249.

16. Garcia-Contreras R, Scougall-Vilchis RJ, Contreras-Bulnes R, Kanda $Y$, Nakajima $H$, Sakagami $H$. Cytotoxicity and pro-inflammatory action of chemo-mechanical caries-removal agents against oral cells. In Vivo 2014;28:549-556.

17. Duque C, Hebling J, Smith AJ, Giro EM, Oliveira MF, de Souza Costa CA. Reactionary dentinogenesis after applying restorative materials and bioactive dentin matrix molecules as liners in deep cavities prepared in nonhuman primate teeth. J Oral Rehabil 2006;33:452-461.

18. Huang FM, Li YC, Lee SS, Chang YC. Cytotoxicity of dentine bonding agents on human pulp cells is related to intracellular glutathione levels. Int Endod J 2010;43:1091-1097.

19. Clària J. Cyclooxygenase-2 biology. Curr Pharm Des 2003;9:2177-2190.

20. Couper KN, Blount DG, Riley EM. IL-10: the master regulator of immunity to infection. J Immunol 2008;180:5771-5777.

21. Yang F, Xu N, Li D, Guan L, He Y, Zhang Y, et al. A feedback loop between RUNX2 and the E3 ligase SMURF1 in regulation of differentiation of human dental pulp stem cells. J Endod 2014;40:1579-1586.

22. Han N, Zheng $Y$, Li R, Li X, Zhou M, Niu Y, et al. $\beta$-catenin enhances odontoblastic differentiation of dental pulp cells through activation of Runx2. PLoS One 2014;9:e88890.

23. Daltoé MO, Paula-Silva FW, Faccioli LH, Gatón-Hernández PM, De Rossi A, Bezerra Silva LA. Expression of Mineralization Markers during Pulp Response to Biodentine and Mineral Trioxide Aggregate. J Endod 2016:42:596-603.

24. Ganss B, Kim RH, Sodek J. Bone sialoprotein. Crit Rev Oral Biol Med. 1999;10:79-98.

25. Ogata Y. Bone sialoprotein and its transcriptional regulatory mechanism. J Periodontal Res 2008;43:127-135.

26. Pagel CN, Wasgewatte Wijesinghe DK, Taghavi Esfandouni N, Mackie EJ. Osteopontin, inflammation and myogenesis: influencing regeneration, fibrosis and size of skeletal muscle. J Cell Commun Signal 2014;8:95103.

27. Saito $K$, Nakatomi M, Ida-Yonemochi H, Kenmotsu S, Ohshima H. The expression of GM-CSF and osteopontin in immunocompetent cells precedes the odontoblast differentiation following allogenic tooth transplantation in mice. J Histochem Cytochem 2011;59:518-529.

28. Saito K, Nakatomi M, Ida-Yonemochi H, Ohshima H. Osteopontin Is Essential for Type I Collagen Secretion in Reparative Dentin. J Dent Res 2016;95:1034-1041.

29. Scatena M, Liaw L, Giachelli CM. Osteopontin: a multifunctional molecule regulating chronic inflammation and vascular disease. Arterioscler Thromb Vasc Biol 2007;27:2302-2309.

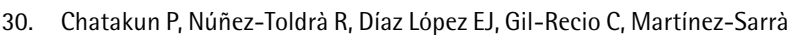
$E$, Hernández-Alfaro $F$, et al. The effect of five proteins on stem cells used for osteoblast differentiation and proliferation: a current review of the literature. Cell Mol Life Sci. 2014;71:113-142.

Received January 14, 2019

Accepted June 9, 2019 